\title{
MOVEMENT PROJECTION OF AIRCRAFT PASSENGERS AT HALIM PERDANA AIRPORT
}

\author{
Anita Yulyanti \\ Jurusan Teknik Dirgantara-Sekolah Tinggi Teknologi Adisutjipto \\ anitayulyantii@gmail.com
}

\begin{abstract}
Air transportation is increasingly in demand.. Airports as a gathering place for passengers must be prepared to face this increase in the number of aircraft passengers. This increase in airplane passengers certainly affects and is influenced by various socio-economic factors, including: population, number of hotels, number of tourists, GRDP (Gross Regional Domestic Product), and number of train passengers. Halim Perdana Kusuma Airport could be considered as new airports in Indonesia because it has only been used for commercial flights for 7 years starting from opening for public flights in 2014. This airport has visually increased the number of passengers each year so it is suitable as an object of research. Calculation of the estimated increase in airplane passengers at the airport can be done using a multiple linear regression method, while to find out how much influence the size of the increase in airplane passengers and socio-economic factors can use the correlation coefficient search
\end{abstract}

Keyword: Transportation, GRDP And Passerngers

\section{Latar Belakang}

Kebutuhan sarana transportasi umum merupakan salah satu kebutuhan masyarakat yang terus berkembang sejalan dengan semakin meningkatnya taraf kehidupan ekonomi masyarakat. Adanya peningkatan kebutuhan sarana transportasi tidak lepas dari keinginan masyarakat untuk mendapatkan sarana transportasi yang baik dengan kriteria aman, cepat, murah, dan nyaman. Perubahan-perubahan selera yang terjadi dalam pemilihan jenis sarana angkutan tidak lepas pula dari adanya perkembangan sosial ekonomi masyarakat serta kemajuan teknologi.Berdasarkan hal tersebut diperlukan suatu sarana transportasi yang lebih banyak jumlahnya dan dapat memenuhi kebutuhan masyarakat akan transportasi yang aman dan cepat dengan disertai pelayanan yang memadai. Saat ini, angkutan transportasi udara merupakan salah satu alat transportasi yang digemari masyarakat di era globalisasi yang serba cepat ini [1][2]. Pergerakan masyarakat dari satu tempat ke tempat lain sangatlah tinggi. Ini juga disertai pada kenyataan bahwa jalur udara memiliki peran strategis dalam pembangunan nasional karena Indonesia adalah negara kepulauan yang dikelilingi oleh wilayah laut yang sedemikian luas. Kenyataan juga membuktikan bahwa arus peredaran barang dan manusia semakin tergantung pada angkutan udara karena daya angkutnya yang semakin besar, dan biaya yang semakin murah. Dari sisi geografis luas negara kepulauan menjadi ruang gerak yang baik bagi jenis angkutan udara dengan pesawat terbang.Di sisi lain, dengan transportasi yang lancar, dapat digunakan untuk memperluas daerah pemasaran, dimana dulu distribusi barang untuk ke daerah (pulau) lain tidak dapat terjangkau dengan moda angkutan darat maupun laut, sekarang tentunya dapat dijangkau oleh moda angkutan udara. Dengan semakin berkembangnya teknologi yang berdampak pada kemajuan industri penerbangan menuntut pula kemajuan pada faktor penunjangnya. Dimana faktor penunjang dari industri penerbangan adalah dibutuhkan sarana dan prasarana yang mempunyai efek, baik langsung maupun tidak langsung terhadap industri penerbangan. Salah satu efek langsung dari perkembangan industri penerbangan adalah bandar udara [3][4]. Ketersediaan bandar udara suatu daerah sangat berpengaruh akan peningkatan ekonomi masyarakat daerah tersebut, selain sebagai tempat pendaratan maupun 
keberangkatan pesawat terbang, diharapkan dapat meningkatkan potensi pariwisata, bisnis, dan perdagangan yang dimiliki daerah tersebut. Bandara Halim Perdana Kusuma sebelumnya adalah pangkalan udara yang hanya digunakan untuk kepentingan militer sejak 1985. Kini bandara ini memegang peranan penting dalam perekonomian setelah dibuka kembali untuk penerbangan komersial pada tahun 2014 [5]. Seiring berjalannya waktu jumlah penumpang bandara ini semakin meningkat. Analisis ini bertujuan untuk mengetahui prediksi pergerakan penumpang pada tahun 2023 di bandara Halim Perdana Kusuma beserta faktor sosio-ekonomi yang mempengaruhinya guna mengantisipasi fasilitas-fasilitas pendukung penerbangan demi kenyamanan dan keselamatan penumpang. Dalam melakukan analisis ini penulis menggunakan metode regresi linier berganda. Bandar udara adalah suatu tempat di darat, di laut atau di air dimana pesawat udara dapat mendarat menurunkan atau mengangkut penumpang dan barang, perbaikan atau pemeliharaan juga pengiriman bahan bakar dan kegiatan lainnya. Secara umum suatu bandar udara harus mampu melayani aktivitas perhubungan udara sesuai jam operasi (operating hours) dengan menjamin keselamatan penerbangan, kelancaran dan keteraturan penerbangan.Kegiatan angkutan udara dalam negeri (domestik) seluruhnya dilakukan oleh Perusahaan Penerbangan Nasional (Perusahaan Pemerintah dan Swasta), sedangkan untuk penerbangan luar negeri (internasional) dilakukan oleh perusahaan penerbangan asing dan perusahaan penerbangan nasional [6].Transportasi udara umumnya dibagi ke dalam tiga golongan, yakni angkutan udara, penerbangaan umum, dan militer. Kategori penerbangan swasta dan umum selain penerbangan terjadwal yang dilakukan perusahaan penerbangan (airlines) meliputi juga penerbangan pribadi dan yang digunakan oleh industri swasta dan komersial untuk mengirimkan barang ataupun alat-alat dan hasil produksi. Dalam kategori penerbangan umum juga termasuk kegiatan penerbangan yang sifatnya non-transport, misalnya untuk keperluan inspeksi penerbangan, pemadaman kebakaran, dan lain-lain. Letak suatu Bandar Udara akan dipengaruhi oleh faktor-faktor berikut:

a) Tipe pengembangan sekitarnya

b) Kondisi-kondisi atmosfer meteorology

c) Kemudahan untuk dicapai dengan transportasi darat

d) Ketersediaan lahan

e) Adanya Bandar Udara yang lain dan ketersediaan ruang angkasa dalam daerah tersebut

f) Halangan sekeliling

g) Keekonomisan biaya konstruksi

h) Ketersediaan utilitas

i) Keeratan (proximity) dengan permintaan aeronotika.

Passenger adalah setiap orang yang diangkut maupun yang harus diangkut di dalam pesawat udara ataupun di dalam pesawat udara ataupun badan pesawat menyelenggarakan angkutan tersebut [7]. Begitu pula bisnis transportasi udara. Potensi penumpang yang besar tentu semakin membuka peluang bagi berbagai pihak untuk semakin besar potensi penumpang di suatu daerah tersebut. Begitu pula dengan pihak-pihak lain yang berkaitan dengan bisnis penerbangan, mulai dari operator bandar udara, pengusaha hotel, pariwisata, dan lainlain.Maka dari itu perlu dilakukan perhitungan terhadap potensi pergerakan di suatu daerah, termasuk halim perdana Kusuma. Hal ini penting karena dengan mengetahui potensi pergerakan penumpang di daerah tersebut, dapat diketahui langkah-langkah apa saja yang harus dilakukan untuk menghadapi potensi penumpang yang ada di masa yang akan datang. Bangkitan dan tarikan adalah tahapan permodelan yang memperkirakan jumlah pergerakan yang berasal dari suatu zona atau tata guna lahan dan jumlah pergerakan yang berasal dari suatu tata guna atau zona. Pergerakan lalu lintas merupakan fungsi tata guna lahan yang 
menghasilkan pergerakan lalu lintas [8][9]. Tahapan ini bertujuan mempelajari dan meramalkan besarnya tingkat bangkitan dan tarikan pergerakan dengan mempelajari beberapa variasi hubungan dengan lingkungan. Bangkitan dan tarikan pergerakan yang terjadi, baik bangkitan maupun tarikan, misalnya tata guna lahan, pemilik kendaraan, populasi, jumlah pekerjaan, kepadatan penduduk, pendapatan dan lain-lain.Transportasi adalah pemindahan barang dan manusia dari tempat asal ke tempat tujuan. Di samping itu, manajemen transportasi memiliki sasaran dalam menghasilkan produk atau jasa di dalam organisasinya, bahwa sasaran dalam manajemen angkutan ialah memperkecil harga tambahan, ini memerlukan keahlian dalam usaha pengadaan alat angkutan yang tepat jenisnya bagi suatu tugas tertentu yang harus dilaksanakan.Fungsi utama sebuah Bandar Udara sama halnya seperti sebuah terminal dimana dalam hal ini melayani penumpang pesawat udara, sebagai tempat pemberhentian, pemberangkatan, ataupun sekedar persinggahan pesawat udara (transit). Di dalamnya terjadi berbagai macam rangkaian kegiatan yang berkaitan dengan pesawat terbang, seperti mengangkut / menurunkan penumpang.Bandar udara digunakan untuk memproses penumpang dan bagasi untuk pertemuan dengan pesawat dan moda transportasi darat. Bandar udara juga digunakan untuk penanganan pengangkutan barang (cargo)

\section{Metodologi Penelitian}

a) Objek Penelitian

Objek penelitian dalam melakukan penelitian ini meliputi data jumlah penumpang di Bandar Udara Halim Perdanakusuma Jakarta dan data Sosio Ekonomi. Adapun data-data yang dibutuhkan diantaranya data jumlah penumpang per tahun di Bandar Udara Halim Perdana Kusuma Jakarta data jumlah penduduk, jumlah hotel, jumlah wisatawan, jumlah tenaga kerja, jumlah Panjang jalan $(\mathrm{km})$, jumlah penumpang kereta, produk domestik regional bruto (PDRB).

b) Metode Pengumpulan Data

Metode pengumpulan data yang digunakan yaitu Buku/referensi dengan mengumpulan data yang berasal dari instansi terkait atau yang berasal dari literatur buku-buku berada pada perpustakaan yang berkaitan dengan judul Tugas Akhir ini maupun dari referensi lainnya dan metode wawancara, metode ini merupakan suatu cara pengambilan data yang dilakukan dengan melakukan tanya jawab terhadap orang yang berkompeten di bidang ini. Alur Analisis Potensi Pergerakan Penumpang Pesawat di Bandara Halim Perdanakusuma adalah

\section{$>$ Rumusan masalah, Tujuan Penelitian dan Batasan Masalah}

Yang membatasi mengenai ruang lingkup permasalahan yang akan diteliti sehingga pokok pembahasan tidak melebar jauh dari pokok pembahasan sehingga dapat terarah dan terpusat terhadap masalah yang akan diteliti. Rumusan masalah merupakan rumusan pikiran atau ide yang tertuang dalam pikiran terhadap masalah yang akan diteliti. Penetapan tujuan merupakan suatu usaha yang hendak dicapai dalam penelitian setelah merumuskan dan membatasi masalah terhadap permasalahan yang dibahas sehingga dapat menemukan dan menetapkan suatu tujuan terhadap objek yang akan diteliti.

$>$ Pengolahan Data

Setelah data dikumpulkan data selanjutnya diolah untuk mendapatkan informasi dan data yang cukup. 
Informasi dan Data yang cukup

Di tahap ini untuk menentukan proses alur penelitian lanjut ke tahap berikutnya atau mengulang kembali dari pengumpulan data, bila informasi dan data kurang.

Analisis data dan pembahasan

Setelah mendapatkan data-data yang diperlukan, maka dilakukan perhitungan untuk mengetahui potensi pergerakan penumpang pesawat terbang di Bandara halim perdanakusuma Jakarta.

\section{Hasil dan Pembahasan}

Dalam pengumpulan data dan observasi penelitian didapatkan data dari unit airport operation Bandar Udara Halim Perdana Kusuma Jakarta ditunjukkan pada tabel di bawah ini :

Tabel 1 Jumlah Kedatangan dan Keberangkatan Penumpang

\begin{tabular}{|c|c|c|c|}
\hline \multirow{2}{*}{ No } & \multicolumn{3}{|c|}{$\begin{array}{c}\text { Jumlah Pergerakan Penumpang Pesawat di Bandar Udara } \\
\text { Halim Perdana Kusuma Jakarta }\end{array}$} \\
\cline { 2 - 4 } & \multirow{2}{*}{ Tahun } & \multicolumn{2}{|c|}{ Penumpang Dalam Negeri } \\
\cline { 3 - 4 } & & 775334 & Berangkat \\
\hline 1 & 2014 & 1473207 & 767490 \\
\hline 2 & 2015 & 2807480 & 2780951 \\
\hline 3 & 2016 & 3433623 & 3309394 \\
\hline 4 & 2017 & 3712096 & 3570129 \\
\hline 5 & 2018 & \multicolumn{2}{|c|}{ Datang } \\
\hline
\end{tabular}

Selama periode tahun 2014 s.d. 2018 jumlah kedatangan dan keberangkatan penumpang selalu mengalami peningkatan, baik untuk penumpang datang maupun berangkat.Data sosial ekonomi adalah kedudukan atau posisi seseorang dalam kelompok masyarakat yang ditentukan oleh jenis aktivitas ekonomi, pendidikan serta pendapatan. Dalam pembahasannya sosial dan ekonomi sering menjadi objek pembahasan yang berbeda.

Tabel 2 Jumlah Penduduk

\begin{tabular}{|c|c|}
\hline Tahun & $\begin{array}{c}\text { Jumlah } \\
\text { Penduduk }\end{array}$ \\
\hline 2014 & 10076220 \\
\hline 2015 & 10177924 \\
\hline 2016 & 10277628 \\
\hline 2017 & 10374235 \\
\hline 2018 & 10467629 \\
\hline Jumlah & 51373636 \\
\hline
\end{tabular}

Table 3 Jumlah Hotel

\begin{tabular}{|c|c|}
\hline Tahun & Jumlah Hotel \\
\hline 2014 & 432 \\
\hline 2015 & 440 \\
\hline 2016 & 437 \\
\hline 2017 & 432 \\
\hline 2018 & 768 \\
\hline Jumlah & 2509 \\
\hline
\end{tabular}


Table 4 Jumlah Wisatawan

\begin{tabular}{|c|c|}
\hline Tahun & Jumlah Wisatawan \\
\hline 2014 & 26461933 \\
\hline 2015 & 29848339 \\
\hline 2016 & 31080070 \\
\hline 2017 & 33330985 \\
\hline 2018 & 32115352 \\
\hline Jumlah & 152836679 \\
\hline
\end{tabular}

Tabel 5 Jumlah Produk Domestic Regional Bruto (PDRB)

\begin{tabular}{|c|c|}
\hline Tahun & PDRB \\
\hline 2014 & 176232 \\
\hline 2015 & 198909 \\
\hline 2016 & 215907 \\
\hline 2017 & 236536 \\
\hline 2018 & 259917 \\
\hline Jumlah & 1087501 \\
\hline
\end{tabular}

Tabel 6 Jumlah Penumpang Kereta

\begin{tabular}{|c|c|}
\hline Tahun & $\begin{array}{c}\text { Demand } \\
(Y)\end{array}$ \\
\hline 2014 & 232868089 \\
\hline 2015 & 279733840 \\
\hline 2016 & 302792422 \\
\hline 2017 & 315844991 \\
\hline 2018 & 336798524 \\
\hline Jumlah & 1468037866 \\
\hline
\end{tabular}

Dengan menggunakan metode Analisis Regresi Linier Berganda, dengan mengetahui Jumlah Penduduk dan jumlah PDRB pada tahun 2023. Dapat diramalkan juga Jumlah penumpang tahun 2023.

Tabel 7 Persentase Kenaikan Jumlah Penduduk 2014-2018

\begin{tabular}{|c|c|c|}
\hline Tahun & Jumlah Penduduk & $\begin{array}{c}\text { Persentase } \\
\text { kenaikan }\end{array}$ \\
\hline 2014 & 10.076 .220 & \\
\hline 2015 & 10.177 .924 & $1,009 \%$ \\
\hline 2016 & 10.277 .628 & $0,980 \%$ \\
\hline 2017 & 10.374 .235 & $0,940 \%$ \\
\hline 2018 & 10.467 .629 & $0,900 \%$ \\
\hline Persentase Kenaikan Rata-rata & $0,957 \%$ \\
\hline
\end{tabular}


Jumlah penduduk pada tahun $2023=$ jumlah penduduk pada tahun $2018 \times(1+$ (rata-rata pertumbuhan $\times 5)$

Jumlah Penduduk Tahun $2023=10.467 .629 \times(1+(0,957 \times 5)$

Jumlah Penduduk Tahun $2023=10.968 .659$

Tabel 7 Persentase Kenaikan Jumlah PDRB 2014-2018

\begin{tabular}{|c|c|c|}
\hline Tahun & PDRB & $\begin{array}{c}\text { Persentase } \\
\text { kenaikan }\end{array}$ \\
\hline 2014 & 176.232 & \\
\hline 2015 & 198.909 & $12,868 \%$ \\
\hline 2016 & 215.907 & $8,546 \%$ \\
\hline 2017 & 236.536 & $9,555 \%$ \\
\hline 2018 & 259.917 & $9,885 \%$ \\
\hline Persentase Kenaikan Rata-rata & $10,213 \%$ \\
\hline
\end{tabular}

Jumlah PDRB Tahun $2023=$ Jumlah PDRB Tahun $2018 \times(1+($ rata-rata pertumbuhan $\times 5)$

Jumlah PDRB Tahun $2023=259.917 \times(1+(10,213 \times 5)$

Jumlah PDRB Tahun $2023=392.646$

Hasil peramalan Jumlah Kedatangan Penumpang di Bandar Udara Halim Perdana Kusuma Jakarta tahun 2023 sebagai berikut:

$\mathrm{Y}_{2023}=-337100568,896+35,863 \mathrm{X}_{1}-113,067 \mathrm{X}_{4}$

$\mathrm{Y}_{2023}=-337100568,896+35,863(10.968 .659)-113,067(392.646)$

$\mathrm{Y}_{12023}=4.020 .280$

Sehingga hasil peramalan Jumlah Kedatangan Penumpang di Bandar Udara Halim Perdana Kusuma Jakarta tahun 2023 adalah sebanyak 4.020.280 orang.

Dengan menggunakan metode Analisis Regresi Linier Berganda, dengan mengetahui Jumlah Penduduk dan jumlah PDRB pada tahun 2023. Dapat diramalkan juga Jumlah penumpang tahun 2023.

Tabel 8 Persentase Kenaikan Jumlah Penduduk 2014-2018

\begin{tabular}{|l|l|l|}
\hline Tahun & Jumlah Penduduk & $\begin{array}{l}\text { Persentase } \\
\text { kenaikan }\end{array}$ \\
\hline 2014 & 10.076 .220 & \\
\hline 2015 & 10.177 .924 & $1,009 \%$ \\
\hline 2016 & 10.277 .628 & $0,980 \%$ \\
\hline 2017 & 10.374 .235 & $0,940 \%$ \\
\hline 2018 & 10.467 .629 & $0,900 \%$ \\
\hline \multicolumn{2}{|l|}{ Persentase Kenaikan Rata-rata } & $0,957 \%$ \\
\hline
\end{tabular}

Jumlah Penduduk Tahun $2023=$ Jumlah Penduduk Tahun $2018 \times(1+($ rata-rata pertumbuhan $\times 5)$

Jumlah Penduduk Tahun $2023=10.467 .629 \times(1+(0,957 \times 5)$ 
Jumlah Penduduk Tahun $2023=10.968 .659$

Tabel 9 Persentase Kenaikan Jumlah PDRB 2014-2018

\begin{tabular}{|c|c|c|}
\hline Tahun & PDRB & $\begin{array}{c}\text { Persentase } \\
\text { kenaikan }\end{array}$ \\
\hline 2014 & 176.232 & \\
\hline 2015 & 198.909 & $12,868 \%$ \\
\hline 2016 & 215.907 & $8,546 \%$ \\
\hline 2017 & 236.536 & $9,555 \%$ \\
\hline 2018 & 259.917 & $9,885 \%$ \\
\hline \multicolumn{2}{|l|}{ Persentase Kenaikan Rata-rata } & $10,213 \%$ \\
\hline
\end{tabular}

Jumlah PDRB Tahun $2023=$ Jumlah PDRB Tahun $2018 \times(1+($ rata-rata pertumbuhan $\times 5)$ Jumlah PDRB Tahun $2023=259.917 \times(1+(10,213 \times 5)$

Jumlah PDRB Tahun $2023=392.646$

Hasil peramalan Jumlah Penumpang di Bandar Udara Halim Perdana Kusuma Jakarta tahun 2023 sebagai berikut:

$\mathrm{Y}_{2023}=-332.904 .841,553+35,446 \mathrm{X}_{1}-113,035 \mathrm{X}_{4}$

$\mathrm{Y} 2_{2023}=-332.904 .841,553+35,446(10.968 .659)-113,035(392.646)$

$\mathrm{Y} 2_{2023}=3.676 .578$

Sehingga hasil peramalan Jumlah Keberangkatan Penumpang di Bandar Udara Halim

Perdana Kusuma Jakarta tahun 2023 adalah sebanyak 3.676.578 orang.

\section{Kesimpulan}

Karakteristik sosial-ekonomi yang paling kuat korelasinya dengan pertumbuhan penumpang transportasi udara di Bandara Halim Perdana Kusuma Jakarta adalah jumlah penduduk dan nilai PDRB, baik terhadap jumlah kedatangan penumpang maupun jumlah keberangkatan penumpang.Koefisien korelasi berganda antara jumlah penduduk dan nilai PDRB terhadap jumlah total penumpang, kedatangan penumpang dan keberangkatan penumpang pesawat udara di Bandara Halim Perdana Kusuma Jakarta secara berturut-turut adalah 0,998; 0,999; dan 0,997. Hasil peramalan penumpang transportasi udara di Bandara Halim Perdana Kusuma pada tahun 2023 adalah:

a. Jumlah penumpang pesawat udara di bandara Halim Perdana Kusuma Jakarta adalah 4.020.280'

b. Jumlah penumpang pesawat udara di bandara Halim Perdana Kusuma Jakarta adalah 3.676 .578

\section{Daftar Pustaka}

[1] Adasmita, Sakti Adji. 2012. Perencanaan Infrastruktur Transportasi Wilayah. Graha Ilmu. Yogyakarta.

[2] Damarjati, R. S.. 2001. Istilah Istilah Dunia Pariwisata. PT. Pradnya Paramita. Jakarta.

[3] Ginting, Rosnani. 2007. Sistem Produksi Graha Ilmu. Yogyakarta

[4] Heizer, Jay, and Barry Render. 2009. Principle of Operation Management. Render. $\left(9^{\text {th }}\right.$ Edition). Pearson Education.

[5] Purba, Aleksander. 2009. Analisis Proyeksi Penumpang Bandara Perintis Serai Lampung Barat-Provinsi Lampung. Jurusan Teknik Sipil. Universitas Lampung. Bandar Lampung. 
[6] Setyawan, Tegar. 2013. Analisis Potensi Pergerakan Penumpang Transportasi Udara di DI Yogyakarta.. Sekolah Tinggi Teknologi Adisutjipto. Yogyakarta

[7] Tamin, OZ.. 2008. Perencanaan, Pemodelan, \& Rekayasa Transportasi: Teori, Contoh Soal,dan Aplikasi. Penerbit ITB. Bandung

[8] Utomo, Dian. 2010. Kebijakan Pelayanan Administrasi Terpadu Kecamatan. (PATEN). Direktorat Jenderal Pemerintahan Umum, Kementerian Dalam Negeri Indonesia. Jakarta.

[9] Yarlina, Lita. 2012. Analisis Kapasitas Terminal Penumpang Di Bandar Udara SMB II Palembang. Pusat Penelitian dan Pengembangan Transportasi Udara. Badan Penelitian dan Pengembangan Perhubungan. Departemen Perhubungan Indonesia. Jakarta. 